\title{
A Decade Of Reformasi: Unsteady Democratisation ${ }^{1}$
}

\section{Willy Purna Samadhi Nicolaas Warouw}

This article is based on two surveys on the state of democracy in Indonesia in order to assess the progress made by actors of democracy following the reformasi, bringing the authoritarian rule under Soeharto to an end after almost three decades in power. The efforts were a response to a conference in January 2002 on the democracy movement from which a recommendation assigned a task force to carry out an academically sound nationwide survey that would facilitate the discussion of a fresh agenda for democratisation. The task force appointed a team of researchers and constituted Demos, a research group, to support the research and follow up the results. The first survey had been carried out in two rounds, in 2003 and 2004, while the second was conducted in 2007. The report of the first survey has now been published as Making Democracy Meaningful: Problems and Options in Indonesia (Priyono et.al. 2007) suggesting a deficit in Indonesia's democracy Indonesia through the widening gap between, on the one hand, comparatively remarkable civil-political freedoms and, on the other, by the poor condition of operational instruments. ${ }^{2}$

Both surveys were methodologically based on a pioneering framework for the assessment of democracy from below. They combined theories and experiences drawn from studies of rights, institutions, as well as social and political movements. Extensive interviews were held out with experienced and knowledgeable campaigners. The participants were carefully selected expert-informants who were activists of democracy movement actively working within certain issues in thirty-two provinces. The informants had spent between four to six hours each answering more than 300 questions on 13 key-variables of problems and options of meaningful human rights-based democracy. The survey team may, of course, have set aside some crucial questions, and the local experts from 
around the country may sometimes be mistaken in their assessment. It was assumed that unless one came to mobilise theoretically convincing arguments and more solid data to suggest that critical aspects had been set aside, that the informants were generally mistaken, or that the team had made faulty calculations and poor analysis, the surveys may well comprise the most comprehensive and systematic information currently available on the problems of, and options for, human rights-based democracy in Indonesia. In addition, the approach is new and the result is the most comprehensive body of research-based information available on the topic so far. Almost all the informants chose to answer the questions in relation to their local contexts, thus possibly increasing the quality of their information. One may thus hope that the results of the survey would form the point of departure for both improvements and discussion on a more efficient agenda for meaningful human rights-based democracy.

\section{The state and dynamics of democracy: On Methodology}

Prior to presenting the results of the 2007 Survey and comparing it with those of the 2003-2004 Survey, some issues regarding methodology needs clarification.

The survey was conducted by asking our informants for assessments in all provinces in Indonesia. There were 798 informants in the first survey, and 903 in the second. The informants interviewed were experienced activists with good track record as promoters of democracy. They were leaders of the democratic movement on several frontlines: ${ }^{3}$

1. Movement for peasant and fisherman

2. Labour movement

3. Movements for urban poor society

4. Human Right upholding and protection

5. Anti-corruption and good governance

6. Democratisation of the political party system

7. Pluralism and conflict reconciliation

8. Democratisation of education

9. Improvements of professionalism

10. Freedom of press and journalism

11. Gender equality

12. Alternative representation at local level

13. Sustainable development

Assessment on the situation and the dynamics of democracy required from the informants is classified into three aspects. The first aspect relates to the performance and the scope of the instruments of democracy. The identification and the assessment of the aspect is based on approach introduced by David Beetham ${ }^{4}$ Nonetheless, Demos, since the 2007 Survey, has made some necessary adjustments to the Beetham's instruments in accord with particular circumstances experienced in Indonesia (Priyono 
et.al., 2007). We shall return to this aspect shortly when discussing the capacity of actors of democracy in promoting and putting the instruments of democracy into operation, as well as the extent the actors are capable of doing so.

The second aspect for assessment is the capacity of the actors to promote and use the instruments of democracy relevant to their particular circumstances and interests. This is crucial as the overall assessment of democracy and democracy as process do not occur in a vacuum. A comprehension of the capacity of the actors involved in the process would not merely help to understand the progress of democracy. It, equally, leads to an understanding of the strength and weakness of the actors. The application of this second aspect will, in turn, allow the current survey to provide insights as the basis for drawing recommendations to activists promoting democracy.

The study on whether and how the actors actually establish relationships with democracy makes up the third aspect. Do they both promote it and use it, or just use it? Do they tend to manipulate it, or disregard it and, instead, make attempt to influence politics and people in other ways considered to be against the principles of democracy? This aspect is relevant to the sense that democracy provides opportunity for every member of a community to exercise equal political control on matters mutually agreed. It helps to ascertain the extent democratisation and its actual situation give benefit to the majority or, instead, undercut the public role and fail to become a channel for the demos.

We shall now return to the first aspect. The 2003-2004 Survey was conducted in two stages. From the instruments list used by Beetham et.al, Demos identified 35 instruments of democracy during the first stage. Later, during the second stage, the list was reformulated to contain 40 instruments in order to obtain more accurate information about the implementation of democracy. During the 2007 Survey, however, for practical reasons, the list was simplified, without losing the substance, to only contain 32 instruments of democracy as shown in Box 1 below. 


\section{Box 1. The Instruments of Democracy}

1 Citizenship (Equal state-citizenship; The rights of minorities, migrants and refugees, Reconciliation of horizontal conflicts

2 Government support of international law and UN human rights

3 Subordination of the government and public officials to the rule of law

4 The equality before the law (Equal and secure access to justice; The integrity and independence of the judiciary)

5 Freedom from physical violence and the fear of it

6 Freedom of speech, assembly and organisation

7 Freedom to carry out trade union activity

8 Freedom of religion, belief; language and culture

9 Gender equality and emancipation

10 The rights of children

11 The right to employment, social security and other basic needs

12 The right to basic education, including citizen's rights and duties

13 Good corporate governance

14 Free and fair general elections (Free and fair general elections at central, regional and local level; Free and fair separate elections of e.g. governors, mayors and village heads)

15 Freedom to form parties on the national or local level (or teams of independent candidates) that can recruit members, and participate in elections

16 Reflection of vital issues and interests among people by political parties and or candidates

17 Abstention from abusing religious or ethnic sentiments, symbols and doctrines by political parties and or candidates.

18 Independence of money politics and powerful vested interests by political parties and or candidates

19 Membership-based control of parties, and responsiveness and accountability of parties and or political candidates to their constituencies

20 Parties and or candidates ability to form and run government

21 Democratic decentralisation of government of all matters that do not need to be handled on central levels.

22 The transparency and accountability of elected government, the executive, (bureaucracies), at all levels

23 The transparency and accountability of the military and police to elected government and the public

24 The capacity of the government to combat paramilitary groups, hoodlums and organised crime

25 Government independence from foreign intervention (except UN conventions and applicable international law)

26 Government's independence from strong interest groups and capacity to eliminate corruption and abuse of power

27 Freedom of the press, art and academic world

28 Public access to and the reflection of different views within media, art and the academic world

29 Citizens' participation in extensive independent civil associations

30 Transparency, accountability and democracy within civil organisations

31 All social groups' - including marginalised groups - extensive access to and participation in public life

32 Direct participation (People's direct access and contact with the public services and government's consultation of people and when possible facilitation of direct participation in policy making and the execution of public decisions) 
Informants were requested to assess the performance and the scope of each instrument in their own specific regional context. The question, firstly, dealt with whether applicable rules and regulations existed at all before they were asked to make assessment on what they had been doing in a particular field of instrument. This was meant to investigate the extent of the existing formal rules and regulations were able or otherwise to generate the desired output. What was the extent of, for example, the existing rules and regulations were supposed to foster freedom of speech, assembly and organisation? Moreover, in order to identify the scope of instruments of democracy, informants were requested to make assessment in two ways. Firstly, the geographic scope of the implementation of the instrument. Secondly, the extent of the substance of freedom of speech, assembly and organisation impacted in applicable rules and regulations? The ideal retort to both requests would, certainly, describe instruments being widely spread and substantially performed. Table 1 below features the comparison of the index for each instrument of democracy.

Table 1. Instruments of democracy Index:

2003-2004 and 2007 Survey results

\begin{tabular}{|c|c|c|c|}
\hline NO & INSTRUMENTS OF DEMOCRACY & $\begin{array}{c}\text { INDEX } \\
2003-2004\end{array}$ & $\begin{array}{l}\text { INDEX } \\
2007\end{array}$ \\
\hline \multicolumn{4}{|c|}{ Legal instruments and Rights } \\
\hline 1 & $\begin{array}{l}\text { Citizenship (Equal state-citizenship; The rights of minori- } \\
\text { ties, migrants and refugees, Reconciliation of horizontal } \\
\text { conflicts) }\end{array}$ & 32 & 42 \\
\hline 2 & $\begin{array}{l}\text { Government support of international law and UN hu- } \\
\text { man rights }\end{array}$ & 27 & 47 \\
\hline 3 & $\begin{array}{l}\text { Subordination of the government and public officials to } \\
\text { the rule of law }\end{array}$ & 16 & 44 \\
\hline 4 & $\begin{array}{l}\text { The equality before the law (equal and secure access to } \\
\text { justice; The integrity and independence of the judiciary) }\end{array}$ & 18 & 44 \\
\hline 5 & Freedom from physical violence and the fear of it & 28 & 47 \\
\hline 6 & Freedom of speech, assembly and organisation & 74 & 60 \\
\hline 7 & Freedom to carry out trade union activity & 57 & 51 \\
\hline 8 & Freedom of religion, belief; language and culture & 74 & 65 \\
\hline 9 & Gender equality and emancipation & 47 & 46 \\
\hline 10 & The rights of children & 27 & 53 \\
\hline 11 & $\begin{array}{l}\text { The right to employment, social security and other basic } \\
\text { needs }\end{array}$ & 22 & 45 \\
\hline 12 & $\begin{array}{l}\text { The right to basic education, including citizen's rights } \\
\text { and duties }\end{array}$ & 37 & 59 \\
\hline 13 & Good corporate governance & 21 & 39 \\
\hline
\end{tabular}




\begin{tabular}{|c|c|c|c|}
\hline \multicolumn{4}{|c|}{ Political Representation } \\
\hline 14 & $\begin{array}{l}\text { Free and fair general elections (Free and fair general } \\
\text { elections at central, regional and local level; Free and fair } \\
\text { separate elections of e.g. governors, mayors and village } \\
\text { heads) }\end{array}$ & 63 & 64 \\
\hline 15 & $\begin{array}{l}\text { Freedom to form parties on the national or local levels } \\
\text { (or teams of independent candidates) that can recruit } \\
\text { members, and participate in elections }\end{array}$ & 71 & 40 \\
\hline 16 & $\begin{array}{l}\text { Reflection of vital issues and interests among people by } \\
\text { political parties and or candidates }\end{array}$ & 24 & 36 \\
\hline 17 & $\begin{array}{l}\text { Abstention from abusing religious or ethnic sentiments, } \\
\text { symbols and doctrines by political parties and or candi- } \\
\text { dates. }\end{array}$ & 38 & 44 \\
\hline 18 & $\begin{array}{l}\text { Independence of money politics and powerful vested } \\
\text { interests by political parties and or candidates }\end{array}$ & 20 & 40 \\
\hline 19 & $\begin{array}{l}\text { Membership-based control of parties, and responsiveness } \\
\text { and accountability of parties and or political candidates } \\
\text { to their constituencies }\end{array}$ & 23 & 37 \\
\hline 20 & $\begin{array}{l}\text { Parties and or candidates ability to form and run govern- } \\
\text { ment }\end{array}$ & 24 & 37 \\
\hline \multicolumn{4}{|c|}{ Democratic and Accountable Government } \\
\hline 21 & $\begin{array}{l}\text { Democratic decentralization of government of all matters } \\
\text { that do not need to be handled on central levels. }\end{array}$ & 33 & 42 \\
\hline 22 & $\begin{array}{l}\text { The transparency and accountability of elected govern- } \\
\text { ment, the executive (and bureaucracies), at all levels }\end{array}$ & 23 & 43 \\
\hline 23 & $\begin{array}{l}\text { The transparency and accountability of the military and } \\
\text { police to elected government and the public }\end{array}$ & 23 & 34 \\
\hline 24 & $\begin{array}{l}\text { The capacity of the government to combat paramilitary } \\
\text { groups, hoodlums and organised crime }\end{array}$ & 20 & 38 \\
\hline 25 & $\begin{array}{l}\text { Government independence from foreign intervention (ex- } \\
\text { cept UN conventions and applicable international laws) }\end{array}$ & 24 & 36 \\
\hline 26 & $\begin{array}{l}\text { Government's independence from strong interest groups } \\
\text { and capacity to eliminate corruption and abuse of power }\end{array}$ & 18 & 43 \\
\hline \multicolumn{4}{|c|}{ Civic Engagement and Participation } \\
\hline 27 & Freedom of the press, art and academic world & 60 & 59 \\
\hline 28 & $\begin{array}{l}\text { Public access to and the reflection of different views } \\
\text { within media, art and the academic world }\end{array}$ & 57 & 46 \\
\hline 29 & $\begin{array}{l}\text { Citizens' participation in extensive independent civil } \\
\text { associations }\end{array}$ & 62 & 54 \\
\hline 30 & $\begin{array}{l}\text { Transparency, accountability and democracy within civil } \\
\text { organisations }\end{array}$ & 42 & 48 \\
\hline 31 & $\begin{array}{l}\text { All social groups' - including marginalized groups - ex- } \\
\text { tensive access to and participation in public life }\end{array}$ & 46 & 38 \\
\hline 32 & $\begin{array}{l}\text { Direct participation (People's direct access and contact } \\
\text { with public services and government's consultation of } \\
\text { people and, when possible, facilitation of direct partici- } \\
\text { pation in policy making and the, execution of public } \\
\text { decisions) }\end{array}$ & 25 & 39 \\
\hline \multicolumn{2}{|r|}{ INDEX SCORE AVERAGE } & 37 & 46 \\
\hline
\end{tabular}




\section{Democracy in Indonesia: A contemporary overview}

Generally speaking, the results from the first survey pointed to four major conclusions concerning the problems and options for how to promote human rights-based democracy in Indonesia:

1. Basic freedoms were present, but some other rights and organisational instruments of democracy experienced severe deficit.

2. There were free and fair elections, participated, however, only by parties and politicians without democratic representation and accountability to constituents.

3. The elites had been increasingly adjusted to the formal rules of democracy as legitimate means to boost their vested-interest.

4. Despite the reintroduction of formal democracy, the real agents of change for democracy, namely activists and pressure groups from civil society, remained unable to make real impacts.

The survey by Demos in $2007^{5}$ indicates that the standard of the rules and regulations supposed to promote democracy in Indonesia have improved, particularly, in relation to the operational instruments of governance. Some instruments of democracy-such as, independence of executive power from vested-interest groups, capacity to eradicate corruption, lessening abuse of power, subordination of government and public officials to the rule of law, as well as equality before the law-are showing remarkable progress. It is admitted, however, that the progress emerges only from poor initial conditions. The democratic political framework appears to be working well and gaining acceptance. Most actors seem to have accepted democracy as the 'only game in town'. Most remarkably, attempts from the old elements to reintroduce a centralised state as found during the New Order era in post-1998 had received less sympathy from subjects in outer islands. Therefore, concern about the recurrence of eastern European experience of territorial disintegration following the end of the authoritarian regime does not seem to have its empirical ground. Instead, as this survey suggests, people appears to want to give way to democracy as means to increasingly implement a nationwide democratic political community.

Nevertheless, the progress does not, in itself, improve the expression of democracy in a real sense. Firstly, the improvement in the operation of instruments of democracy departs from a very poor situation, leaving the standard remains insufficient. Secondly, the narrowing down of gap between warranted freedoms and poor instruments of democracy may also be regarded as the result of decline in the quality of most aspects of fundamental freedoms. Thirdly, political representation, interestbased representation, and direct representation by the people have largely stagnated. In addition, the deterioration of quality of democracy is, ironically, related to the freedom to form parties and participate in 
elections at all levels. Fourthly, political practices remain elite-dominated. Fifthly, politicisation of issues and interests, organisation, and political mobilisation are top-down driven and characterised by clientelism and populism. Lastly, pro-democrats are beginning to engage in political action and no longer just active at the society level. They, nevertheless, continue being poorly organised, fragmented, and marginalised from electoral participation, thus making them increasingly cynical of representative democracy and opting primarily for forms of direct participation. In short, the structure of democracy with remarkable progress seems to be erected on sand and its foundation remains poor.

Although democracy has been ever more functioning as a system and a national political framework, representation remains the most persistent problem. Considerable progress is lacking in three dimensions of representation: party-based political representation, interest representation based on civil associations and social movements, and direct participation. As long as these dimensions are not included in the main agenda of political democratisation, Indonesian democracy continues to be monopolised by the interests of the oligarchic elite. At least, this is the sign clearly reflected in the country's current party system.

Compared with the 2003-2004 Survey, some fundamental aspects of freedom have noticeably declined. A regression occurs as one compares the current situation with the relative freedom enjoyed by the citizens during the early years of reformasi. This was when citizen's participation and freedom to establish political parties and several aspects related to political representation were apparent. Indonesia's democratization also suffers from additional problems such as lack of improved access and participation for all social groups, particularly marginalised groups, in public life, the poor condition of gender equality, the persistent low standards of military and police transparency and accountability to the elected government and the public, as well as strong government dependence on foreign intervention.

A decade later, Indonesia's path toward democracy has shown both progress and deterioration or stagnation. As a national political framework, democracy works and has been relatively successful, compared to some other countries. Nonetheless just as any structure built on sand, Indonesian democracy lacks a strong foundation.

\section{Public cynicism of pro-elite politics ${ }^{6}$}

The result from recent survey indicates public cynicism of politics as clearly revealed from informants' answer to the question of how, in their opinion, people understand politics. A large number of informants assessed that people understood politics as being elite business (12\%) or elitist manipulation (17\%). If both are summed together, the result is relatively far above the informant group believing that the people deem politics to mean public's control over public matters (14\%). The data clearly shows that the public is not familiar with politics, and that it bears elitist connotations. 
In addition, more than half (54\%) of informants believed that the people considered politics as a struggle for power. This statement has a double meaning. It may be interpreted as a positive expression, that the informants perceive politics as an opportunity for the public to struggle for their interests, or as an expression of cynicism toward the elitist characteristics of politics. Nonetheless, observing the trend of informant's assessments and the poor image of the political parties in public's view, it is reasonable to argue that the opinion of politics as a struggle for power leads to the second connotation.

Additional data reveals that the people are, to some extent, interested in politics. At least $60 \%$ of the informants stated that the people are interested or even very interested in politics. This means that although the people do have interest in politics, they feel that they do not have the same access to it as the elites, thus making the picture an irony.

Table 2. People's Interest in Politics:

Comparison between 2007 National Survey and 2006/07 Aceh Survey

\begin{tabular}{|c|l|c|c|}
\hline \multirow{2}{*}{ NO } & \multicolumn{1}{|c|}{ PEOPLE'S INTEREST IN POLITICS } & $\begin{array}{c}\text { NATIONAL } \\
\text { SURVEY }^{1}\end{array}$ & $\begin{array}{c}\text { ACEH } \\
\text { SURVEY }^{2}\end{array}$ \\
\cline { 3 - 4 } & \multicolumn{1}{|c|}{ (\% OF INFORMANTS) } \\
\hline 1 & $\begin{array}{l}\text { Highly interested (aware and actively involved in } \\
\text { making and achieving democratic changes) }\end{array}$ & 14 & 28 \\
\hline 2 & Interested (political process participation) & 46 & 55 \\
\hline 3 & $\begin{array}{l}\text { Not interested (floating/passive without awareness to } \\
\text { achieve change) }\end{array}$ & 40 & 16 \\
\hline
\end{tabular}

Number of informants 798.

${ }^{2}$ Number of informants 199; Source: http://www.demosindonesia.org/aceh

Table 3. Women's Interest in Politics:

Comparison between 2007 National Survey and 2006/07 Aceh Survey

\begin{tabular}{|c|c|c|c|}
\hline \multicolumn{4}{|c|}{ How do you rate political interest of the women involved in your regional movement? } \\
\hline \multirow[t]{2}{*}{ NO } & \multirow[t]{2}{*}{ WOMEN'S INTEREST IN POLITICS } & $\begin{array}{l}\text { NATIONAL } \\
\text { SURVEY }^{1}\end{array}$ & $\begin{array}{l}\text { ACEH } \\
\text { SURVEY }^{2}\end{array}$ \\
\hline & & \multicolumn{2}{|c|}{ (\% OF INFORMANTS) } \\
\hline 1 & $\begin{array}{l}\text { Highly interested (aware and actively involved in } \\
\text { making and achieving democratic changes) }\end{array}$ & 6 & 12 \\
\hline 2 & Interested (political process participation) & 42 & 47 \\
\hline 3 & $\begin{array}{l}\text { Not interested (floating/passive without awareness to } \\
\text { achieve change) }\end{array}$ & 50 & 39 \\
\hline
\end{tabular}

${ }^{2}$ Number of informants 199; Source: http://www.demosindonesia.org/aceh

Aceh provides results with a different picture. A separate survey in Aceh, conducted in 2006-2007, reveals more positive results ${ }^{7}$ showing that $36 \%$ of informants in Aceh understood politics as public control over public matters. This number clearly went far beyond the $14 \%$ obtained from 
the national survey. Indication of a low political elitism trend was shown in only $23 \%$ of Acehnese informants who believed that people considered politics as the business and playground of the elites, compared to $29 \%$ in the overall national survey.

In line with that, $85 \%$ of informants in Aceh believed that Acehnese were interested or even very interested in politics, compared to the $70 \%$ of the national survey. Similarly, Acehnese informants also assessed women's interest in politics in a more positive way, compared to those in the national survey. Their assessment shows a more positive situation regarding women's interest to politics in Aceh as seen in Table 2 and 3

What should be noted first from the comparison between two surveys is that they show people being more optimistic in responding to the political situation and democracy both in Aceh and Indonesia as a whole. Noting that the survey in Aceh was conducted during the postconflict time following the Helsinki agreement, it can be considered that the situation in Aceh has been a positive implication of the peace agreement signed between Free Aceh Movement (Gerakan Aceh Merdeka/GAM) and the Indonesian government. Law No. 11/2006 on Aceh Government, among other things, regulates the matter of the existence of local parties and independent candidates in local elections. This can be viewed as a democratic opening at local level, which is, unfortunately, absent in rest of the country. In addition, the data also indicates that democratisation and political openness in Aceh, so far, have not led to a potential separatism, as feared by many. On the contrary, it might even become a model to promote democracy from below, starting from local level.

\section{Impressive Advances: Governance-related aspects}

Since the fall of the New Order, formal rules and regulations as well as informal arrangements have become increasingly supportive of democracy as they began to be widely accepted as a way of governing the people and as the language of power politics. Democracy becomes a relatively well functioning system as a national political framework, ${ }^{8}$ replacing the former authoritarian political system. In other word, democracy moves ahead, albeit little by little, toward progress. In an optimistic scenario, this has been made possible following the dramatic improvements of civil and political rights in the early years of democratisation.

Remarkable progress is apparent in the field of government's general performance rule of law. On average, indexes of eight instruments related to aspects of governance improve by almost 100\% (from 22 to 42; see Table 4). It is possible that the trend could have been caused by, among other reasons, agenda by the current administration under President Susilo Bambang Yudhoyono and Vice President Jusuf Kalla, emphasizing reform of those badly performing aspects. Another may be caused by the actual situation at local level following the implementation of regional autonomy. 
Table 4. Index of instruments of democracy related to aspects of governance: 2003-2004 and 2007 results

\begin{tabular}{|c|c|c|c|c|c|}
\hline \multirow{2}{*}{ NO } & \multirow{2}{*}{$\begin{array}{l}\text { NO OF } \\
\text { INSTRUMENTS }\end{array}$} & \multirow{2}{*}{$\begin{array}{l}\text { INSTRUMENTS RELATED TO } \\
\text { ASPECTS OF GOVERNANCE }\end{array}$} & \multicolumn{2}{|c|}{$\begin{array}{l}\text { INDEX AND } \\
\text { RANK }^{(1)}\end{array}$} & \multirow{2}{*}{$\begin{array}{c}\text { INDEX } \\
\text { INCREASE } \\
(\%)\end{array}$} \\
\hline & & & 2003-2004 & 2007 & \\
\hline 1 & 3 & $\begin{array}{l}\text { Subordination of the government } \\
\text { and public officials to the rule of } \\
\text { law }\end{array}$ & $16(32)$ & $45(16)$ & 181 \\
\hline 2 & 4 & $\begin{array}{l}\text { The equality before the law (Equal } \\
\text { and secure access to justice; The } \\
\text { integrity and independence of the } \\
\text { judiciary) }\end{array}$ & $18(30)$ & $44(15)$ & 144 \\
\hline 3 & 21 & $\begin{array}{l}\text { Democratic decentralization of } \\
\text { government of all matters that do } \\
\text { not need to be handled on central } \\
\text { levels. }\end{array}$ & $33(14)$ & $43(20)$ & 30 \\
\hline 4 & 22 & $\begin{array}{l}\text { The transparency } \\
\text { and accountability of } \\
\text { elected government, the } \\
\text { executive,(bureaucracies), at all } \\
\text { levels }\end{array}$ & $23(24)$ & $43(19)$ & 87 \\
\hline 5 & 23 & $\begin{array}{l}\text { The transparency and } \\
\text { accountability of the military and } \\
\text { police to elected government and } \\
\text { the public }\end{array}$ & $23(23)$ & $35(32)$ & 52 \\
\hline 6 & 24 & $\begin{array}{l}\text { The capacity of the government } \\
\text { to combat paramilitary groups, } \\
\text { hoodlums and organised crime }\end{array}$ & $20(28)$ & $39(26)$ & 95 \\
\hline 7 & 25 & $\begin{array}{l}\text { Government's independence from } \\
\text { foreign intervention }\end{array}$ & $24(20)$ & $36(30)$ & 50 \\
\hline 8 & 26 & $\begin{array}{l}\text { Government's independence } \\
\text { from strong interest groups and } \\
\text { capacity to eliminate corruption } \\
\text { and abuse of power }\end{array}$ & $18(31)$ & $43(18)$ & 139 \\
\hline \multicolumn{3}{|c|}{ AVERAGE INDEX } & 22 & 41 & 97 \\
\hline
\end{tabular}

Some critical notes are worth noting. First, the fact that more corruption cases are brought to trial shows not only government' commitment to eradicate corruption, but also underlines the fact that corruption remains pervasive. The second critical note is that improvements that relate to governance do not in itself indicate positive performance in good governance. Table 4 shows that the index score for governance-related instruments was small and the rank of the respective instruments was low. When compared to the score of other instruments, as seen in Table 1 , democratic instruments related to practices of governance were ranked low. Subordination of the government and public officials to the rule of law had the highest index score (45) of all instruments related to governance and ranked $16^{\text {th }}$ out of 32 . 
Table 5. The Instruments of Democracy with Index Score $\leq 40$

\begin{tabular}{|c|c|c|c|c|}
\hline NO & $\begin{array}{c}\text { NO OF } \\
\text { INSTRUMENTS }\end{array}$ & INSTRUMENTS OF DEMOCRACY(1) & INDEX & RANK \\
\hline 1 & 23 & $\begin{array}{l}\text { The transparency and accountability of the } \\
\text { military and police to elected government and } \\
\text { the public }\end{array}$ & 34 & 32 \\
\hline 2 & 16 & $\begin{array}{l}\text { Reflection of vital issues and interests } \\
\text { among people by political parties and or } \\
\text { candidates }\end{array}$ & 36 & 31 \\
\hline 3 & 25 & $\begin{array}{l}\text { Government independence from foreign } \\
\text { intervention (except UN conventions and } \\
\text { applicable international law) }\end{array}$ & 36 & 30 \\
\hline 4 & 19 & $\begin{array}{l}\text { Membership-based control of parties, } \\
\text { and responsiveness and accountability of } \\
\text { parties and or political candidates to their } \\
\text { constituencies }\end{array}$ & 37 & 29 \\
\hline 5 & 31 & $\begin{array}{l}\text { All social groups' - including } \\
\text { marginalized groups - extensive access to } \\
\text { and participation in public life }\end{array}$ & 38 & 27 \\
\hline 6 & 20 & $\begin{array}{l}\text { Parties and or candidates ability to form } \\
\text { and run government }\end{array}$ & 37 & 28 \\
\hline 7 & 24 & $\begin{array}{l}\text { The capacity of the government to combat } \\
\text { paramilitary groups, hoodlums and organised } \\
\text { crime }\end{array}$ & 38 & 26 \\
\hline 8 & 32 & $\begin{array}{l}\text { Direct participation (People's direct access } \\
\text { and contact with the public services and } \\
\text { government's consultation of people } \\
\text { and when possible facilitation of direct } \\
\text { participation in policy making and the } \\
\text { execution of public decisions)) }\end{array}$ & 39 & 25 \\
\hline 9 & 18 & $\begin{array}{l}\text { Independence of money politics and } \\
\text { powerful vested interests by political } \\
\text { parties and or candidates }\end{array}$ & 40 & 23 \\
\hline 10 & 13 & Good corporate governance & 39 & 24 \\
\hline 11 & 15 & $\begin{array}{l}\text { Freedom to form parties on the national } \\
\text { or local level (or teams of independent } \\
\text { candidates) that can recruit members, and } \\
\text { participate in elections }\end{array}$ & 40 & 22 \\
\hline
\end{tabular}

11) The instruments related to governance are in italics.

The government's impartiality towards vested-interest groups and its capacity to eliminate corruption and abuse of power had previously ranked $31^{\text {st }}$ but is currently ranked $18^{\text {th }}$.A slower shift was found in transparency and accountability of the elected government and the bureaucracy where the rank shifted from $24^{\text {th }}$ to $19^{\text {th }}$. Transparency and accountability of the armed forces and the police force to the elected government and to the public declined from the $23^{\text {rd }}$ to the bottom of the 32 instruments. In other words, three of the instruments of democracy related to the practices of governance were in the list with the worst possible score index $(\leq 40)$. See Table 5 . 


\section{Threats to fundamentals of democracy}

\section{Withering freedoms}

As in the previous survey, instruments related to freedoms and civil and political rights were in good shape compared to other instruments. Nonetheless, when compared with the earlier survey, the 2007 Survey indicated a deterioration in the instruments of democracy.

Freedom of religion and cultural expression remained high. Freedom of speech, assembly, and organisation was still among the best although had shifted from second to the third place. Free and fair general elections improvede moving from fourth to second place. Moreover, freedom from physical violence and fear improved its position from $16^{\text {th }}$ to $10^{\text {th }}$ place.

The index of instruments related to civil and political rights were relatively better compared to other instruments. As seen in Table 6 below, six out of 11 instruments of democracy with index scores above the overall average $(>46)$ were those related to freedom and civil and political rights.

Table 6. The Instruments of Democracy

with Index above Average Index Score (>46)

\begin{tabular}{|c|c|c|c|c|}
\hline NO & $\begin{array}{c}\text { NO OF } \\
\text { INSTRUMENT }\end{array}$ & INSTRUMENTS OF DEMOCRACY(1) & INDEX $^{(2)}$ & RANK $^{(2)}$ \\
\hline 1 & 8 & $\begin{array}{l}\text { Freedom of religion, belief; language and } \\
\text { culture }\end{array}$ & $65(74)$ & $1(1)$ \\
\hline 2 & 14 & $\begin{array}{l}\text { Free and fair general elections (Free and } \\
\text { fair general elections at central, regional } \\
\text { and local level; Free and fair separate } \\
\text { elections of e.g. governors, mayors and } \\
\text { village heads) }\end{array}$ & $64(63)$ & $2(4)$ \\
\hline 3 & 6 & Freedom of speech, assembly and organization & $60(74)$ & $3(2)$ \\
\hline 4 & 12 & $\begin{array}{l}\text { The right to basic education, including } \\
\text { citizen's rights and duties }\end{array}$ & $59(37)$ & $4(13)$ \\
\hline 5 & 27 & Freedom of the press, art and academic world & $59(60)$ & $5(6)$ \\
\hline 6 & 29 & $\begin{array}{l}\text { Citizens' participation in extensive } \\
\text { independent civil associations }\end{array}$ & $54(62)$ & $6(5)$ \\
\hline 7 & 10 & The rights of children & $53(27)$ & $7(18)$ \\
\hline 8 & 7 & Freedom to carry out trade union activity & $51(57)$ & $8(8)$ \\
\hline 9 & 30 & $\begin{array}{l}\text { Transparency, accountability and } \\
\text { democracy within civil organizations }\end{array}$ & $48(42)$ & $9(11)$ \\
\hline 10 & 5 & $\begin{array}{l}\text { Freedom from physical violence and the fear } \\
\text { of it }\end{array}$ & 47 (28) & $10(16)$ \\
\hline 11 & 28 & $\begin{array}{l}\text { Public access to and the reflection of different } \\
\text { views within media, art and the academic } \\
\text { world }\end{array}$ & $46(57)$ & $11(7)$ \\
\hline
\end{tabular}

1) The instruments written in italics are related to freedom and civil and political rights

(2) The numbers in brackets indicate the results of 2003-2004 Survey 
Though listed as the best instruments, most instruments representing fundamental aspects of democracy-freedoms and civil and political rights - in fact experienced deterioration or, at least, stagnation. The instruments related to freedom of religion, belief, language and culture previously ranked at the top with an index score of 74 , decreased to an index score of 66. The index for freedom of speech, assembly and organisation, previously with an index score of 74 , was down to 60 . The index of instruments related to freedom to establish trade unions and carry out activities shifted from 57 to 51 .

The decline in the index in political freedom and civil rights appears likely to be confirmed by realities on the ground. The banning of Jamaah Islamiyah Indonesia from exercising its religious freedom, and the pressure placed on individuals in localised religious sects (e.g. Lia Aminuddin of Jamaah Salamullah, Ahmad Mushadek of Al-Qiyadah AlIslamiyah) to condemn their beliefs and to conform with the mainstream interpretation by the state-sanctioned authority have created grave concerns for the condition of civil rights. In addition, a religious decree, or fatwa, issued by the council of Islamic clerics (Majelis Ulama Indonesia, MUI) forbidding discourse of pluralism, liberalism and tolerance is likely to make the fundamentals of democracy worse.

Table 7. Instruments of Democracy related to freedoms and civil and political rights whose indexes decreased:

Comparison of 2003/04 and 2007 Survey results.

\begin{tabular}{|c|c|c|c|c|c|}
\hline \multirow{2}{*}{ NO } & \multirow{2}{*}{$\begin{array}{l}\text { NO OF } \\
\text { INSTRUMENT }\end{array}$} & \multirow{2}{*}{$\begin{array}{l}\text { INSTRUMENTS OF } \\
\text { DEMOCRACY }\end{array}$} & \multicolumn{2}{|c|}{ INDEX } & \multirow{2}{*}{ CHANGE } \\
\hline & & & 2003/04 & 2007 & \\
\hline 1 & 6 & $\begin{array}{l}\text { Freedom of speech, assembly and } \\
\text { organisation }\end{array}$ & 74 & 60 & $-19 \%$ \\
\hline 2 & 7 & $\begin{array}{l}\text { Freedom to carry out trade union } \\
\text { activity }\end{array}$ & 57 & 51 & $-11 \%$ \\
\hline 3 & 8 & $\begin{array}{l}\text { Freedom of religion, belief; } \\
\text { language and culture }\end{array}$ & 74 & 65 & $-11 \%$ \\
\hline 4 & 9 & Gender equality and emancipation & 47 & 46 & $-2 \%$ \\
\hline 5 & 27 & $\begin{array}{l}\text { Freedom of the press, art and } \\
\text { academic world }\end{array}$ & 60 & 59 & $-2 \%$ \\
\hline 6 & 28 & $\begin{array}{l}\text { Public access to and the reflection } \\
\text { of different views within media, } \\
\text { art and the academic world }\end{array}$ & 57 & 46 & $-18 \%$ \\
\hline \multicolumn{3}{|c|}{ Average index score } & 62 & 55 & $-15 \%$ \\
\hline
\end{tabular}

It is unfortunate that the current government has demonstrated a degree of tolerance for the elements within the society responsible for such violations. It seems that maintaining its 'populist' image, by appeasing the dominant groups' anger toward the practices of the minority, is more important to the present administration. The government, hence, has failed to defend political freedom and civil rights. ${ }^{9}$ Having said that, it is 
timely to understand why the state of democratic freedoms and civil rights has declined.

\section{Representation as the worst problem and the sharp deterioration of participation}

Threats to the fundamental aspects of democracy cannot, however, be exclusively viewed from the declining conditions of political and civil rights. Other fundamental aspects, such as political representation and government's impartiality, which performed poorly in 2003-2004 Survey and appear to be stagnant in the 2007 Survey, may similarly contribute to weakened fundamentals. The index related to freedom to form parties either at national or local level took a nose dive from 71 to 40 and was situated in $22^{\text {nd }}$ position out of the 32 instruments. Table 8 below shows the index of democratic instruments related to the aspect of political representation.

Table 8. Index and Ranking of Instruments related to Political Representation

\begin{tabular}{|c|c|c|c|c|}
\hline NO & $\begin{array}{c}\text { NO OF } \\
\text { INSTRUMENTS }\end{array}$ & $\begin{array}{l}\text { INSTRUMENTS RELATED TO } \\
\text { POLITICAL REPRESENTATION }\end{array}$ & $\begin{array}{l}\text { INDEX } \\
2007^{(1)}\end{array}$ & RANK $^{(1)}$ \\
\hline 1 & 14 & $\begin{array}{l}\text { Free and fair general elections (Free and fair } \\
\text { general elections at central, regional and } \\
\text { local level; Free and fair separate elections of } \\
\text { e.g. governors, mayors and village heads) }\end{array}$ & $64(63)$ & $2(4)$ \\
\hline 2 & 15 & $\begin{array}{l}\text { Freedom to form parties on the national } \\
\text { or local level (or teams of independent } \\
\text { candidates) that can recruit members, and } \\
\text { participate in elections }\end{array}$ & $40(71)$ & $22(3)$ \\
\hline 3 & 16 & $\begin{array}{l}\text { Reflection of vital issues and interests among } \\
\text { people by political parties and or candidates }\end{array}$ & $36(24)$ & $31(22)$ \\
\hline 4 & 17 & $\begin{array}{l}\text { Abstention from abusing religious or ethnic } \\
\text { sentiments, symbols and doctrines by } \\
\text { political parties and or candidates. }\end{array}$ & $44(38)$ & $17(12)$ \\
\hline 5 & 18 & $\begin{array}{l}\text { Independence of money politics and } \\
\text { powerful vested interests by political parties } \\
\text { and or candidates }\end{array}$ & $40(20)$ & $23(29)$ \\
\hline 6 & 19 & $\begin{array}{l}\text { Membership-based control of parties, } \\
\text { and responsiveness and accountability of } \\
\text { parties and or political candidates to their } \\
\text { constituencies }\end{array}$ & $37(23)$ & $29(25)$ \\
\hline 7 & 20 & $\begin{array}{l}\text { Parties and or candidates ability to form and } \\
\text { run government }\end{array}$ & $37(24)$ & $28(21)$ \\
\hline 8 & 32 & $\begin{array}{l}\text { Direct participation (People's direct access } \\
\text { and contact with the public services; } \\
\text { Government's consultation of people } \\
\text { and when possible facilitation of direct } \\
\text { participation in policy making and the } \\
\text { execution of public decisions) }\end{array}$ & $39(25)$ & $25(19)$ \\
\hline \multicolumn{3}{|r|}{ INDEX SCORE AVERAGE } & $43(36)$ & \\
\hline
\end{tabular}


As the table shows, instruments related to aspects of political representation do not indicate substantial improvement. On average, the score indexes of instruments in the 2007 Survey related to the aspects of political representation were not particularly high (43) and only increased by $18 \%$ from 36 in the 2003-2004 Survey. In fact, the ranking of six of the eight instruments declined. This demonstrates the negligence of aspects of political representation in the issues of improving democracy.

Serious attention should be paid to two findings. Firstly, the indicator regarding free and fair elections was the only one of eight instruments related to the aspect of representation with a relatively high and consistent index score. According to both the 2003-2004 Survey and the 2007 Survey, the score index for the instrument was above the average index score for all instruments. This indicates that the institutionalisation of free and fair elections tended to be regarded as the main means to promote representation. The optimistic trend shown by instruments related to free and fair elections does not necessarily improve political representation. In a different situation where the instruments related to general elections should be excluded, then the average score index for the other instruments would only reach 39 .

Secondly, this agonising condition is clearly shown by the decline in the index of instruments related to freedom to form parties and participate in elections from 71 to 40 . The data clearly indicates that the ongoing process of democratisation barely provides sufficient space for broadening participation in order to promote representation.

The situation may just worsen following the newly-introduced law on political parties that holds back the establishment of new parties. The failure of a number of parties to pass the verifying process by the Department of Law and Human Rights indicates a setback. Among the 115 new parties registered with the Department of Law and Human Rights, only 24 passed the process to be legally acknowledged political party according to Law No. 2/2008.

\section{Additional setbacks}

Other fundamental aspect of democracy are social, economic, and cultural rights. The instruments for these aspects are the right to basic education, including citizen's rights and duties; protection of the rights of children; and the right to employment, social security and other basic needs, and good corporate governance. The 2007 Survey indicated that indexes for the group of social, economic, and cultural rights were increasing. The results may be somewhat surprising, at least for Jakarta residents who do not have adequate information about improvements of social, economic, and cultural conditions in other parts of the country. The assessment appears to be unbalanced, particularly with the problems in social, economic, and cultural fields encountered by the population in eastern Indonesia, including their poor capacity to struggle for basic rights.

Nonetheless, achievements made in economic, social and cultural 
rights should be treated with reservation especially when the index score remained low at 46. Compared to the previous index of 37, there was no impressive increase only an increase of around $20 \%$. As most mass media suggested, the economic, social and cultural conditions of most of the population remained a great concern. People have been left vulnerable in fulfilling their basic needs, not only because of constant soaring prices, but also because some vital necessities have become scarce. Even the small and medium industrial enterprises have suffered from the drastic hike in fuel prices.

Up to this point, there are four interim conclusions. Firstly, in general terms, improvements in the indexes of the instruments of democracy are apparent. Secondly, the gap between the indexes of the instruments of democracy is narrowing. Thirdly, however, the narrowing gap does not necessarily suggest that all all indexes of instruments have improved. Indexes of instruments related to basic freedoms and partypolitical participation that previously showed good indexes are now lower. Improvement in governance may at worst be at the expense of reduced freedoms. Fourthly, other aspects of fundamentals of democracy, namely, political representation and the independence of government, are not improving. However, aside from the elections, the indexes of the instruments required to promote political participation are not among the worst. Finally, economic, social, and cultural rights seem to have improved in certain parts of the country, although it is obvious that the situation remains unbalanced. The combination of these conclusions reveals a potentially disturbing picture: fundamental aspects of democracy are being at the same time threatened.

\section{Formal democracy remains incomplete}

It is believed by many that Indonesia had completely adopted and implemented most formal rules and regulations necessary to the democratisation process, and that the only task left it to ensure that the actors abide by the rules. However, informants in the survey stated that such belief is incorrect and that democracy has yet to be completely institutionalised.

On average, thirty-five per cent of informants stated that there are no formal rules and regulations regulating the 32 instruments of democracy. Around $35 \%$ or more of informants stated that 17 of the instruments are not regulated by formal rules.

Some instruments, on the one hand, are considered to be formalized, such as those relating to free and fair elections. Approximately $81 \%$ of informants stated that formal rules already exist. Other instruments assessed by more than $70 \%$ of informants as being regulated by formal rules are mainly related to freedom of speech, assembly and organization $(78 \%)$; the right to basic education (78\%); freedom of religion, belief, language, and culture (77\%); freedom of the press, art and academic world (74\%); and freedom to carry out trade union activity $(72 \%)$. 
On the other hand, instruments considered not to be yet formalized are the transparency and accountability of the armed force and the police force to elected government and to the public (53\%); abstention from abuse of ethnic and religious sentiments, symbols and doctrines by political parties and or candidates (51\%); the capacity of parties and or candidates to form and run government (49\%); the capacity of the government to combat paramilitary groups, hoodlums and organised crime (49\%); government independence from foreign intervention (49\%); membershipbased control of parties, and responsiveness and accountability of parties and or political candidates to their constituents (48\%); and extensive access and participation of all social groups-including marginalised groups-in public life $(47 \%)$.

Furthermore, recent survey also suggests that the performance of informal arrangements-customs, norms, value, traditions, etc.-in supporting the infrastructure of democracy is showing a relatively steady trend. On average, sixty four per cent of informants stated that informal arrangements are sufficiently supportive of the infrastructure of democracy. They seem to reject common scepticism suggesting that elements of local culture and democracy do not mix.

\section{Actors' relation to instruments of democracy}

This section discusses the relation between main actors and instruments of democracy. Main actors are categorised into two groups: powerful actors and alternative actors (referred as dominant actors and pro-democratic actors in previous survey). Powerful actors are those who wield real and determining political power, while alternative actors are those with the potential to challenge the power of the powerful actors.

Table 9 and Table 10 below show the background composition of the five main actor groups from the two categories. Both tables show that actors with backgrounds in government, bureaucracy or politics play the biggest role, both as powerful and alternative actors.

Recent survey (2007) shows that actors with a government or bureaucracy background are the highest $(54 \%$; $46 \%$ for powerful actors and $8 \%$ for alternative actors). At the same time, actors with a political or parliamentary background increase significantly. Meanwhile, those coming from business make up $6 \%$, from $12 \%$ during the previous survey. On one hand, it may signal private actors being more independent from politics.

On the other hand, it signifies the need, especially among the alternative actors, to take up a more active role in organised political system and political activities. It is true that actors with non-government organisation (NGO) backgrounds are the largest group of alternative actors. Nonetheless, there is an emerging trend of alternative actors coming from political groups or being informal leaders. 
Table 9. Composition of Five Main Powerful Actor Groups:

Comparison of 2003-2004 Survey and 2007 Survey

\begin{tabular}{|c|l|c|c|}
\hline \multirow{2}{*}{ NO } & \multicolumn{1}{|c|}{ POWERFUL ACTORS } & \multicolumn{2}{c|}{$\begin{array}{c}\text { POWERFUL/ } \\
\text { DOMINANT ACTORS }\end{array}$} \\
\cline { 3 - 4 } & \multicolumn{1}{|c|}{$\begin{array}{c}\mathbf{2 0 0 3 - 2 0 0 4} \\
\text { (N=1.795) }\end{array}$} & $\begin{array}{c}\mathbf{2 0 0 7} \\
\text { (N=1.890) }\end{array}$ \\
\hline 1 & Government/Bureaucracy & 40 & 46 \\
\hline 2 & $\begin{array}{l}\text { Political parties and parliament members } \\
\text { (central+local) }\end{array}$ & 17 & 23 \\
\hline 3 & Religious or ethnic groups and adat councils & 12 & 9 \\
\hline 4 & Police and military; Underworld and militia & 16 & 7 \\
\hline 5 & Business & 12 & 6 \\
\hline
\end{tabular}

Table 10. Composition of Five Main Alternative Actor Groups: Comparison of 2003-2004 Survey and 2007 Survey

\begin{tabular}{|c|l|c|c|}
\hline \multirow{2}{*}{ NO } & \multicolumn{1}{|c|}{ ALTERNATIVE ACTORS } & \multicolumn{2}{|c|}{$\begin{array}{c}\text { ALTERNATIVE/ } \\
\text { PRO-DEMOCRACY } \\
\text { ACTORS }\end{array}$} \\
\cline { 3 - 4 } & \multicolumn{1}{|c|}{$\begin{array}{c}\mathbf{2 0 0 3 - 2 0 0 4} \\
\mathbf{( N = 7 9 8 )}\end{array}$} & $\begin{array}{c}\mathbf{2 0 0 7} \\
(\mathbf{N = 1 . 5 9 0 )}\end{array}$ \\
\hline 1 & $\begin{array}{l}\text { NGOs + Class and Non-class based mass } \\
\text { organisations }\end{array}$ & 41 & 31 \\
\hline 2 & Academicians, the judiciary/law firms, media & 30 & 18 \\
\hline 3 & $\begin{array}{l}\text { Political parties and parliament members } \\
\text { (central+local) }\end{array}$ & 8 & 20 \\
\hline 4 & $\begin{array}{l}\text { Religious or ethnic groups, and adat councils; } \\
\text { Informal leaders }\end{array}$ & 2 & 16 \\
\hline 5 & Government/Bureaucracy & 4 & 8 \\
\hline
\end{tabular}

All the numbers show percentage based on the number of actors for each surveys.

\section{Actors' adaptation to democracy}

How have the two groups of actors developed relations with the instruments of democracy? First, it is found that powerful actors are increasingly integrated into the political system in democracy. Their relation to the existing instruments of democracy has much improved since the previous survey. If the previous survey suggested that only 50\% (16\% and $33 \%$ ) of the dominant actors promoted and or used the instruments, recent survey shows that the number has increased significantly. According to the informants, an average of $36 \%$ of powerful actors tends to use the instruments, and another $35 \%$ even promote them, bringing the total to $71 \%$.

The alternative actor group shows a similar performance, with a higher tendency to promote democracy. It is assumed that more than $90 \%(66 \%$ and $27 \%)$ of alternative actors identified by the informants are 
promoting and or using the existing instruments of democracy. This finding is clearly much higher than the situation encountered in the previous survey (66 percent). Table 11 below compares the average trends of the two groups in relation to democracy.

Table 11. Average trend of actors' relation with the instruments of democracy: Comparison between 2003-2004 Survey and 2007 Survey

\begin{tabular}{|c|c|c|c|c|c|c|c|c|c|}
\hline \multirow{4}{*}{ NO } & \multirow{4}{*}{$\begin{array}{c}\text { MAIN } \\
\text { ACTORS }\end{array}$} & \multicolumn{8}{|c|}{ ACTORS' RELATION WITH INSTRUMENTS OF DEMOCRACY } \\
\hline & & \multicolumn{2}{|c|}{$\begin{array}{l}\text { USE AND } \\
\text { PROMOTE }\end{array}$} & \multicolumn{2}{|c|}{ USE } & \multicolumn{2}{|c|}{$\begin{array}{c}\text { USE AND } \\
\text { MANIPULATE }\end{array}$} & \multicolumn{2}{|c|}{$\begin{array}{l}\text { AVOID AND } \\
\text { OPT FOR } \\
\text { ALTERNATIVES }\end{array}$} \\
\hline & & 2003/04 & 2007 & 2003/04 & 2007 & 2003/04 & 2007 & 2003/04 & 2007 \\
\hline & & \multicolumn{2}{|c|}{ (\% OF ACTORS) } & \multicolumn{2}{|c|}{ (\% OF ACTORS) } & \multicolumn{2}{|c|}{ (\% OF ACTORS) } & \multicolumn{2}{|c|}{ (\% OF ACTORS) } \\
\hline 1 & $\begin{array}{l}\text { Dominant/ } \\
\text { Powerful } \\
\text { actors }\end{array}$ & 16 & 35 & 33 & 36 & 36 & 19 & 15 & 10 \\
\hline 2 & $\begin{array}{l}\text { Pro- } \\
\text { democracy/ } \\
\text { Alternative } \\
\text { actors }\end{array}$ & 44 & 66 & 22 & 27 & 20 & 3 & 13 & 4 \\
\hline
\end{tabular}

All numbers show percentages based on the number of actor for each group.

The currently improved relation between main actors and the instruments of democracy indicates the increasing acceptance of democracy as political framework. Powerful actors whose previous attitudes were ambivalent with equally strong tendencies to use and to promote as well as to manipulate and by-pass democratic institutions, are, now, adjusted with the existing instruments. Alternative actors even make democracy the only viable option. Therefore, it is easy to understand the general increase of the index of instruments of democracy.

\section{Insufficient capacity of main actors}

The improved relations between actors and democracy in term of the former committing to promote the latter, have, nonetheless, failed to improve the condition of representation. The incomplete formalisation of instruments of democracy has, accordingly, enabled the interpretation of the substance of each instrument being induced by actors considered to be powerful and, to some extent, by other existing informal factors. Actors' behaviour is mostly based on interests and opportunities according to the ongoing political setting rather than on democratic principles (i.e. public control and wider participation). It is also obvious that improved relations do not necessarily ensure an optimised use of democracy.

Spheres of activity

Compared to the results from previous survey, the 2007 Survey indicates a shift of playing field of alternative actors. In 2003-04, the alternative actors tended to be making distance from the state domain. 
This was apparent from their disinclination in entering and taking part in executive and legislative domain. Currently, political parties become the most important mode of political engagement for these actors. On the one hand, this may be viewed as positive. As the 2003-04 Survey suggested, the absence of alternative actors in these arenas had limited them to marginalised political role. There are, now, opportunities to influence political process on this domain. On the other hand, the phenomenon may also be regarded as a mere shift rather than attempt to broaden their sphere of activities. As a result, the ever-increasing engagement of alternative actors within the state and political parties might be followed by their falling off in civil society organisations. It creates a fear of their expanded playing field not being an adjunct to mandates from the civil society they previously represented. Simultaneously, powerful actors do not show significant changes in regard to their options of sphere of activities. The assessment of informants clearly demonstrates powerful actors dominating state institutions and organised politics.

\section{Sources of power and actors' way of gaining legitimacy}

The powerful actors are also supported by economic power and a well-oiled political machine. Meanwhile, alternative actors rely mainly on their intellectual strength and unorganised mass power. With unlimited financial support, powerful actors are capable in financially supporting their activities, taking part in a number of public issues as political campaigns, getting involved in decision-making processes, and taking advantage for their own vested-interests. In addition to their sustained power monopoly, these actors also become acquainted with the rule of the game in democracy, or, in other words, monopolising democracy. A differing picture from the 2003-04 Survey revealed the same actors were likely to use coercive and manipulative ways in order to legitimate their power. Such ways are, now, becoming outdated and replaced by dialogue, lobbying works, networking, and participation in election.

\section{The politicisation of issues and interests}

It is worth noting the way both powerful and alternative actors pick their issues and interests they represent. The survey reveals that issues and interests represented by both sets of actors are, to a certain degree, analogous. First, the powerful actors begin to get involved in issues that, in the past, would probably be picked only by the alternative actors. Concerns on human rights and building democracy, including freedoms and civil and political rights, are among the issues. The difference is, however, that powerful actors tend to address the issues in terms of general discourse, while the others focus more on detailed and specific cause. Concern on good governance and anti-corruption are common issues often articulated by both sides. Third, both actors seem to focus less on issues and interests related to people's basic needs, such as public services. 
In addition, the survey suggests that the powerful actors, rather than the alternative actors, seem to be paying more attention to macroeconomic issues. This may be related to their specific economic power base crucial in ensuring their existence in politics.

\section{Ways of organising and mobilising support}

The situation with the alternative actors is not less problematic.

They tend to pursue short-term and the narrow-minded goals they have set for themselves in order to take hold of political positions within the system. This, indeed, is quite justified, though creates problem, especially when it involves ways that are against the principles of democracy, and exacerbates the condition of representation. Attempts to grab political seats are often individually-based rather than collectively-driven, supported by methodical mechanism to ensure transparency and accountability. Organisations are mobilised for short-term and individual political agenda, involving only a number of popular figures without real constituents. Even so, they allow alternative actors to rise as newly-introduced charismatic figures. Powerful actors, in contrary, manage to extend their ways to mobilise the masses. In the 2003-04 Survey, the powerful actors seemed to depend on organisations and political machinery to mobilise the masses, in addition to patron-client relations. The 2007 Survey suggests that ways used by powerful actors for political mobilisation have been wide-ranging, as compared to the previous survey.

\section{Strategies}

The failing use of organisations as the basis for mobilisation relates to the strategies of main actors from both groups. Both groups are likely to go for direct participation, rather than mediating institutions. Among alternative actors, 29\% prefer direct participation, while among the powerful actors, the figure reaches 35\%. Alternative actors tend to work with lobbying groups and expert contacts, rather than political parties as legitimate institution in democracy. The same applies to the powerful actors. Despite the findings may reflect pragmatic and short-term strategies of the two groups of actors, they should also be viewed cautiously as an indication of limited capacity of the actors in democratically-driven politics. They, undoubtedly, send negative signals for the process of democracy in the future.

\section{Conclusions}

1. The survey indicates that democratisation, in informants' view, continues to improve. The view is supported by data suggesting an improvement in the index of instruments of democracy. Nonetheless, despite scepticism by some actors about democracy in Indonesia being completely failed is somewhat inaccurate, improvements are taking place on a shaky ground.

2. The improvement in index of democracy is not well distributed in 
all instruments. Progression in index is obvious in the aspects of governance, despite the fact that it does not in itself bring impact to the practices of good government. The condition of social, economical and cultural rights also shows improvement, but does not suggest a satisfying state of affairs. In addition, fundamentals of democracy, such as representation, state independence, and, in particular, basic freedoms are stagnating and falling. Aspects of representation are clearly in a worse situation than before.

3. Meanwhile, the public does not have a chance to become involved in political process. Yet, the experience of Aceh provides a lesson that an open political system can be a rejoinder to the widespread apathy and cynicism to elite politicians.

4. Hence, apart from having to improve its performance in response to the aspects of governance, the government must allow political freedom to improve the condition of poorly-articulated political representation.

5. The process of building the infrastructure of democracy is not yet over. The formalisation of democracy has not yet touched all aspects and, therefore, the ongoing process of democracy must continue.

6. The main actors from the powerful and pro-democracy camps seem to be comparatively adaptive to democracy and its process. It is unfortunate, however, that their capacity is limited. The powerful actors tend to manipulate democracy in favour for their political and economic advantage. Meanwhile, the alternative actors have not managed to show their capability as potential alternative force in democracy. They tend to take shortcuts, rather than to establish organisational base as democratic source, to gain political power. The same applies to the powerful actors, using popular figures to mobilise popular support. 


\section{Endnotes}

1 This article is abridged version of Chapter 1 of Executive Report of Survey on Problems and Options Democracy in Indonesia (Demos 2007). The full text is available in Demos website http://www.demosindonesia.org. For full report of 2007 Survey, see Samadhi and Warouw, Building-Democracy on the Sand (Yogyakarta: PCD Press and Demos, 2009).

2 For a more detailed explanation of democracy deficit, including other results from the 2003-2004 Survey, see Priyono, A.E., W.P Samadhi, O. Tornquist, et.al., Making Democracy Meaningful: Problems and Options in Indonesia (JakartaYogyakarta: Demos and PCD Press, 2007).

3 There were differences in the categorisation between the first and the second survey. The frontline of "Democratisation of the Political Party System" was the combination of attempts to democratise the party system and to form representative political parties. The frontline of "Alternative Representation at Local level" was the combination of improvements of alternative representation at local level and attempts at promoting interest-based mass organisations. In addition, in the second survey another frontline, i.e. "Sustainable Development", was added.

4 David Beetham from Democratic Audit, a research organisation in the Human Rights Centre, University of Essex, assessed the situation of democracy based on the performance of approximately 80 democratic instruments. The approach is then set as the standard for democratic assessment employed by IDEA International. See D. Beetham (1999), Democracy and Human Rights (Oxford: Polity Press) and D. Beetham, S. Bracking, I. Kearton, and S. Weir (2002), International IDEA Handbook and Democracy Assessment (The Hague, London, New York: Kluwer Law International).

5 Data collection was conducted in July-October 2007. The survey is aimed at verifying the main findings of the 2003-2004 Survey. Other than that, the findings were expected to form the basis of recommendations for the pro-democracy activists and movements in anticipation to the 2009 general elections.

6 Data on this part is mainly based on the recent survey. In 2006-2007, Demos conducted a similar survey in Aceh from which the results have been used in comparison with the national data.

7 For results of 2006-2007 Aceh Survey, see http://demosindonesia.org/aceh/ article.php?id=176.

8 The 2003-2004 Survey revealed a similar situation in various regions in Indonesia. This indicates widespread acceptance of the national approach or framework of democratisation throughout the country.

9 For further account, see B.T Naipospos et.al.(2007), "Tunduk pada Penghakiman Massa: Pembenaran Negara atas Persekusi Kebebasan Beragama dan Berkeyakinan," in Laporan Kebebasan dan Berkeyakinan di Indonesia Tahun 2007 (Jakarta: SETARA Institute). 